\title{
重症の糖尿病性ケトアシドーシス症例における 大腿切断術の周術期管理の経験
}

\author{
小寺厚志* 上妻精二* 宮崎直樹* \\ 瀧賢一郎* 江崎公明*
}

[要旨］57歳, 男性. 9年前より糖尿病に対してインスリン加療中であったが, 今回, 下腿の腫 脹と意識障害にて救急搬送された．搬送時の意識状態はJapan Coma Scaleで $\Pi-30$ ，血圧は $73 / 31 \mathrm{mmHg}$, 血糖值は $1,196 \mathrm{mg} / \mathrm{d} l$, 尿中ケトン体は陽性であった． 右下腿壊疽を合併して おり, 重症の糖尿病性ケトアシドーシスと診断し, 緊急の大腿切断術が施行された. 麻酔は自発呼 吸下のケタミン, フェンタニル, プロポフォールによる静脈麻酔で管理した. その周術期管理にお いて, (1)麻酔管理方法, (2)重度アシドーシスの補正, (3)手術侵襲に対する痛覚の評価, (4)意識障害 と術後の痙攣重積発作，(5術後の繰り返す心静止や難治性不整脈に苦慮したが，集学的治療により 軽快し良好な結果を得た。

キーワード : 糖尿病性ケトアシドーシス, 周術期管理, 糖尿病性神経障害

はじめに

下腿壞疽を伴った重症の糖尿病性ケトアシドーシ ス (diabetic ketoacidosis : 以下, DKA) 症例に対す る緊急大腿切断術を静脈麻酔下に管理した。その周 術期管理において，(1)麻酔管理方法，(2)重炭酸ナト リウムによるアシドーシス補正の是非，(3)手術侵襲 に対する痛覚の評価，(4)意識障害と術後の痤攣重積 発作に対する全身管理，5術後の心静止や難治性不 整脈に対する循環管理に苦慮したが，集学的治療で 軽快し良好な結果を得たので報告する。

\section{I 症 例}

57 歳，男性．身長 $165 \mathrm{~cm}$ ，体重 $50 \mathrm{~kg}$.

主訴：意識障害と下腿腫脹。

既往歴：9年前に I 型糖尿病，5年前に糖尿病性 網膜症と診断された。視力は両眼ともに指数弁程度 であった。

現病歴：糖尿病に対して加療中であったが，最近 はインスリンの自己管理を㤐っていた。今回，数日 前より右下腿の発赤，腫脹，異臭に気づいていたが 放置していた。以後，意識障害が出現し発語も見ら れなくなったために救急搬送された。

身体所見：意識状態はJapan Coma Scale(以下,

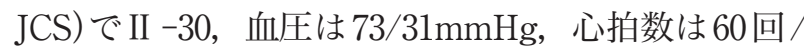
分で整， $6 \mathrm{~L} /$ 分の酸素投与下で酸素飽和度は $100 \%$,

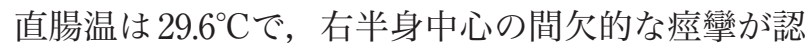
められた。口唇や皮膚は著明に乾燥し, Kussmaul の大呼吸パターンが認められた。口臭が強く呼気の アセトン臭は，はっきりしなかった。右下腿は暗赤 


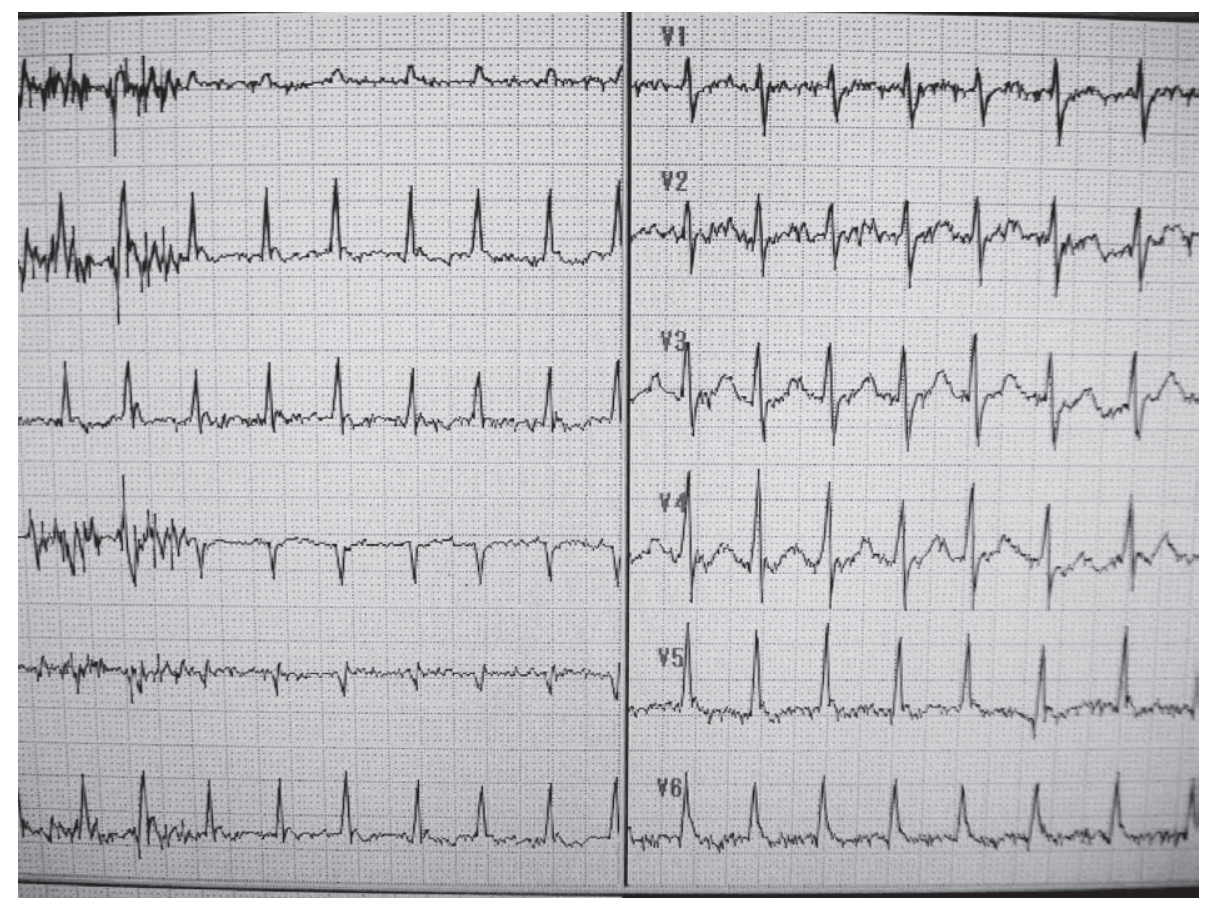

図1 救急搬送時の 12 誘導心電図

痠攣による基線の変動が見られるが， $\mathrm{T}$ 波の増高は見られなかった。

色に変色し，一部で壊死組織が見られた。

検査所見: 血液生化学所見は, $\mathrm{Alb} 2.1 \mathrm{~g} / \mathrm{d} l$, BUN $142 \mathrm{mg} / \mathrm{d} l$, Cre $3.36 \mathrm{mg} / \mathrm{d} l$, Na $132 \mathrm{mEq} / \mathrm{L}$, $\mathrm{K} 6.1 \mathrm{mEq} / \mathrm{L} ， \quad \mathrm{Cl} 91 \mathrm{mEq} / \mathrm{L} ，$ Ca $8.5 \mathrm{mg} / \mathrm{d} l$ ， CK 629 IU/L, WBC 33,100/ $\mu l, \mathrm{Hb} 11.0 \mathrm{~g} / \mathrm{d} l$, Plt $34.1 \times 10^{4} / \mu l$, glucose $1,196 \mathrm{mg} / \mathrm{d} l$, HbAlc $9.9 \%$, CRP $28.75 \mathrm{mg} / \mathrm{d} l$, Lactate $1.8 \mathrm{mmol} / \mathrm{L}$ ，アセ卜酢酸 $5,100 \mu \mathrm{mol} / \mathrm{L} ， 3 \beta$ ヒドロキシ酪酸 $16,200 \mu \mathrm{mol} / \mathrm{L}$ であった。尿一般検 査では尿糖 $(4+)$, 尿ケトン体 $(1+)$ であった。動 脈血血液ガス分析は, $6 \mathrm{~L} /$ 分の酸素投与下で pH 7.030, $\mathrm{PaO}_{2} 300 \mathrm{mmHg}, \mathrm{PaCO}_{2} 24.0 \mathrm{mmHg}$, Base excess $-23.0 \mathrm{mEq} / \mathrm{L}$ であった. 12 誘導心電図 (図1), 胸部単純X線像に異常はなかった。

治療経過：下腿壊疽による敗血症を伴った DKA と診断し, ガイドライン (表 1) ${ }^{1)}$ 基づいて, 代謝 内科医とともに治療を開始した。搬送から手術室を 経て集中治療室に至るまでの検査結果を示す (表 2)。0.9\%生理食塩水による輸液療法とインスリ ンの低用量持続静脈内投与による血糖降下療法を開
始した。 $0.9 \%$ 生理食塩水は, 初めの 4 時間で, $3,000 \mathrm{~m} l(15 \mathrm{~m} l / \mathrm{kg} / \mathrm{hr})$ 投与した。インスリンは 2 単 位をボーラス投与後に, 0.08 単位 $/ \mathrm{kg} / \mathrm{hr}$ で持続投 与し, 目標の血糖值降下速度を約 $100 \mathrm{mg} / \mathrm{d} l / \mathrm{hr}$ と した。そして 2 時間ごとの測定值に応じて 0.04 単位/ $\mathrm{kg} / \mathrm{hr}$ の増減を行った。初めの 2 時間での血糖值降 下速度は目標どおりであった。一方, 痙攣の治療目 的に，フェニトイン $250 \mathrm{mg}$ ，ジアゼパム $10 \mathrm{mg}$ を投 与した。 また，血圧維持のために，ドパミン 5 〜 $10 \mu \mathrm{g} / \mathrm{kg} / \mathrm{min}$, ノルエピネフリン $0.1 \sim 0.15 \mu \mathrm{g} /$ $\mathrm{kg} / \mathrm{min}$ を投与した。

本症例に対して, 敗血症のコントロール目的で, 右下腿壊疽に対して緊急大腿切断術が施行された。

\section{II 麻酔経過}

麻酔経過を示す(図2)。入室時の意識状態はJCS でIII-200(ジアゼパム投与後), 血圧はドパミン $10 \mu \mathrm{g} / \mathrm{kg} / \mathrm{min}, \quad$ ノルピネフリン $0.15 \mu \mathrm{g} / \mathrm{kg} / \mathrm{min}$ 投与下で $99 / 60 \mathrm{mmHg}$ ，心拍数は 104 回/分で整, 
表1 糖尿病性ケトアシドーシスに対する治療ガイドライン

1. 脱水に対する初期の輸液療法

$0.9 \%$ 生理食塩水 $15 \sim 20 \mathrm{ml} / \mathrm{kg} / \mathrm{hr}$ で行う

また代用血漿製剂の併用も考慮する

2. 高血糖に対するインスリン療法

$0.1 \mathrm{U} / \mathrm{kg} / \mathrm{hr}$ の持続投与で行う

1 時間ごとの血糖值降下速度 $(50 \sim 70 \mathrm{mg} / \mathrm{dl})$ を目標とし血糖值に

応じて投与量を徐々に増量する。 ただし $0.2 \mathrm{U} / \mathrm{kg} / \mathrm{hr}$ までの増量

を上限とする

3. 血清カリウムに対する補正

$\mathrm{K}^{+} \geqq 5.0 \mathrm{mEq} / \mathrm{L}$ なら，カリウムは投与せず 2 時間ごとに検査する

$3.3 \leqq \mathrm{~K}^{+}<5.0 \mathrm{mEq} / \mathrm{L}$ なら, カリウムを $20 \sim 30 \mathrm{mEq} / \mathrm{L}$ で適宜投

与し，カリウム值を $4.0 \sim 5.0 \mathrm{mEq} / \mathrm{L}$ の範囲に調節する

4. アシドーシスに対する補正

$\mathrm{pH}<7.0 \quad \mathrm{NaHCO}_{3} \quad 50 \mathrm{ml}(44.6 \mathrm{mmol})$ を投与する

$7.0 \leqq \mathrm{pH} \quad$ 補正は行わない

〔文献1)より翻訳し引用・一部改変〕

表2 救急搬送から集中治療室までの検査結果の推移

\begin{tabular}{|c|c|c|c|c|c|}
\hline & $\begin{array}{l}\text { 治療開始 } \\
\text { (救急搬送) }\end{array}$ & 2 時間後 & $\begin{array}{l}4 \text { 時間後 } \\
\text { (手術室) }\end{array}$ & 6 時間後 & $\begin{array}{l}\text { 8時間後 } \\
\text { (集中治療室) }\end{array}$ \\
\hline $\mathrm{Na}$ 值 & $132 \mathrm{mEq} / \mathrm{L}$ & $136 \mathrm{mEq} / \mathrm{L}$ & $136 \mathrm{mEq} / \mathrm{L}$ & $143 \mathrm{mEq} / \mathrm{L}$ & $147 \mathrm{mEq} / \mathrm{L}$ \\
\hline 補正 Na值 & $149 \mathrm{mEq} / \mathrm{L}$ & $150 \mathrm{mEq} / \mathrm{L}$ & $148 \mathrm{mEq} / \mathrm{L}$ & $153 \mathrm{mEq} / \mathrm{L}$ & $155 \mathrm{mEq} / \mathrm{L}$ \\
\hline K值 & $6.1 \mathrm{mEq} / \mathrm{L}$ & $5.0 \mathrm{mEq} / \mathrm{L}$ & $4.2 \mathrm{mEq} / \mathrm{L}$ & 4.3mEq/L & $4.4 \mathrm{mEq} / \mathrm{L}$ \\
\hline Cl値 & $91 \mathrm{mEq} / \mathrm{L}$ & 99mEq/L & - & - & $110 \mathrm{mEq} / \mathrm{L}$ \\
\hline Ca値 & $8.5 \mathrm{mg} / \mathrm{dl}$ & $7.9 \mathrm{mg} / \mathrm{dl}$ & - & - & $6.6 \mathrm{mg} / \mathrm{dl}$ \\
\hline $\mathrm{HCO}_{3}{ }^{-}$ & 6.3mEq/L & 6.6mEq/L & $10.9 \mathrm{mEq} / \mathrm{L}$ & $17.9 \mathrm{mEq} / \mathrm{L}$ & $24.0 \mathrm{mEq} / \mathrm{L}$ \\
\hline Anion gap & 34.7 & 30.4 & - & - & 7.0 \\
\hline 血糖値 & $1,196 \mathrm{mg} / \mathrm{dl}$ & 996mg/dl & $876 \mathrm{mg} / \mathrm{dl}$ & $719 \mathrm{mg} / \mathrm{dl}$ & $614 \mathrm{mg} / \mathrm{dl}$ \\
\hline BUN値 & $142 \mathrm{mg} / \mathrm{dl}$ & - & - & - & $113 \mathrm{mg} / \mathrm{dl}$ \\
\hline 浸透圧 & $393 \mathrm{mOsm} / \mathrm{kg}$ & - & - & - & $340 \mathrm{mOsm} / \mathrm{kg}$ \\
\hline $\mathrm{pH}$ & 7.030 & 7.010 & 7.000 & 7.170 & 7.280 \\
\hline $\begin{array}{l}\text { Base } \\
\text { excess 值 }\end{array}$ & $-23.0 \mathrm{mEq} / \mathrm{L}$ & $-23.2 \mathrm{mEq} / \mathrm{L}$ & $-19.7 \mathrm{mEq} / \mathrm{L}$ & $-10.3 \mathrm{mEq} / \mathrm{L}$ & $-3.0 \mathrm{mEq} / \mathrm{L}$ \\
\hline
\end{tabular}

補正 $\mathrm{Na}$ 值 $=($ 血糖值 -100$) / 100 \times 1.6+$ 実測 $\mathrm{Na}$ 值

呼吸数は 22 回/分, 酸素飽和度は $6 \mathrm{~L} /$ 分の酸素投与

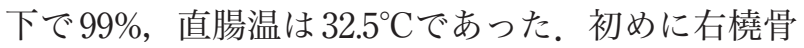
動脈に観血的動脈圧モニタリングを行った。次に右 下腿の創部洗浄が行われたが，血圧上昇や体動は認 められなかった。

アトロピン $0.5 \mathrm{mg}$ の投与後に，ケタミン $0.6 \mathrm{mg} /$ $\mathrm{kg}$ ，プロポフォール $0.4 \mathrm{mg} / \mathrm{kg}$ をボーラス投与し，
続けてケタミン，プロポフォールの持続投与をとも に $1.2 \mathrm{mg} / \mathrm{kg} / \mathrm{hr}$ で開始した。 $1.0 \%$ エピネフリン添 加リドカイン $30 \mathrm{~m} l$ の局所麻酔施行後に手術が開始 された。皮膚切開直前と骨切断直前に，フェンタニ ル $1.0 \mu \mathrm{g} / \mathrm{kg}$ を静脈内投与した。なお，手術中に体 動は認められなかった。

術中の血圧低下に対して，フェニレフリン $0.1 \mathrm{mg}$ 


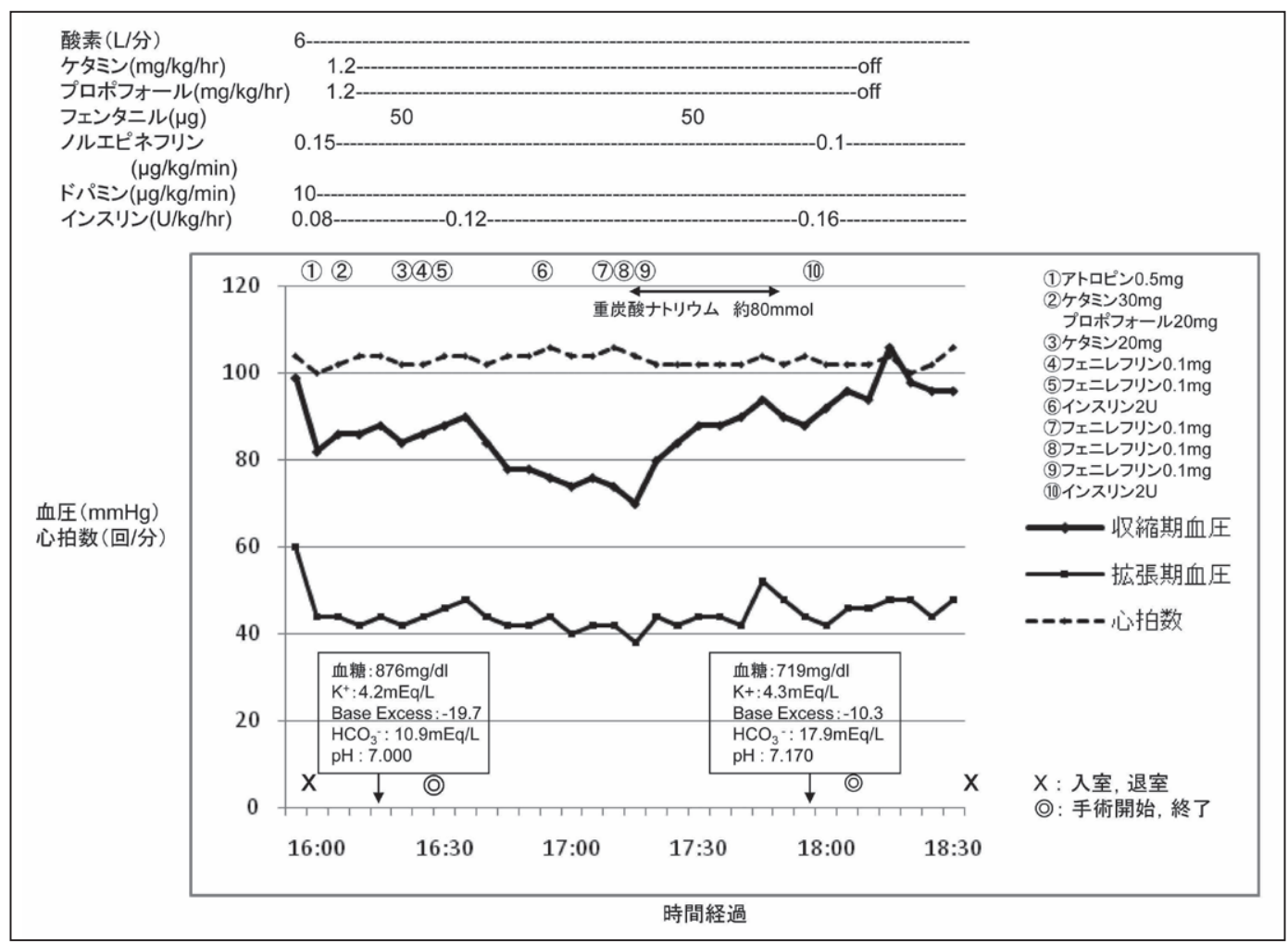

図2 麻酔経過

を頻回に静脈内投与したが血圧は上昇せず，高容量 のカテコラミン下に $68 / 38 \mathrm{mmHg}$ まで低下した。こ れに対して, 重炭酸ナトリウム $100 \mathrm{ml}$ (約 $80 \mathrm{mEq}$ ) にてアシドーシスの補正を行ったところ，血圧は上 昇し安定した循環動態を得た。術中の血糖降下療法 は術前と同様に行った。手術前後 2 時間での血糖值 降下速度が目標以下であったため, インスリン 2 単 位をボーラス投与し，持続投与量を 0.12 単位 $/ \mathrm{kg} /$ $\mathrm{hr} \sim 0.16$ 単位 $/ \mathrm{kg} / \mathrm{hr}$ 順に増量した.

手術終了後にケタミン，プロポフォールの持続投 与を中止した。意識状態は入室時と比べて変化はな かった。 また右半身中心の病攣はプロポフォール中 止後に再び出現した。手術時間 1 時間 43 分, 麻酔 管理時間 2 時間 35 分, 出血量 $153 \mathrm{~g}$, 尿量 $350 \mathrm{ml}$, 総輸液量 $2,200 \mathrm{~m} l$, ケタミン投与量 $180 \mathrm{mg}$, プロポ フォール投与量 $200 \mathrm{mg}$ であった。

\section{III 術後経過}

術後の検査結果の推移を示す(表3). 間欠的な右 半身の痙攣が持続していたが，のちに全身性の痙攣 重積発作となったため，ミダゾラムによる鎮静下に 気管扦管を行った。以後, 頻脈性心房細動と徐脈性 洞調律が交互に見られ，重度の洞不全症候群によっ て循環動態が不安定となった。さらに，約 10 秒程 度の心静止が 4 回繰り返されたが，いずれも心臓、 ッサージ施行後に心拍はすぐに再開した。これに対 する経皮的ペーシングは無効であったが，除細動を 行ったところ, 頻脈性心房細動は消失し洞調律とな つた。これらの集学的治療にて全身状態も改善し, 術後 4 日目に抜管となり,さらに術後 35 日目に退 院となった。 
表 3 術後の検査結果の推移

\begin{tabular}{|c|c|c|c|c|c|}
\hline & 術後 1 日目 & 術後2 日目 & 術後 4 日目 & 術後5日目 & 術後 8 日目 \\
\hline $\mathrm{Na}$ 值 & 148mEq/L & $151 \mathrm{mEq} / \mathrm{L}$ & 139mEq/L & 138mEq/L & $134 \mathrm{mEq} / \mathrm{L}$ \\
\hline 補正 Na値 & $153 \mathrm{mEq} / \mathrm{L}$ & $153 \mathrm{mEq} / \mathrm{L}$ & $141 \mathrm{mEq} / \mathrm{L}$ & 139mEq/L & $134 \mathrm{mEq} / \mathrm{L}$ \\
\hline $\mathrm{K}$ 值 & $4.9 \mathrm{mEq} / \mathrm{L}$ & $5.0 \mathrm{mEq} / \mathrm{L}$ & $4.1 \mathrm{mEq} / \mathrm{L}$ & $3.9 \mathrm{mEq} / \mathrm{L}$ & $4.4 \mathrm{mEq} / \mathrm{L}$ \\
\hline Cl値 & $113 \mathrm{mEq} / \mathrm{L}$ & $116 \mathrm{mEq} / \mathrm{L}$ & $111 \mathrm{mEq} / \mathrm{L}$ & $107 \mathrm{mEq} / \mathrm{L}$ & $101 \mathrm{mEq} / \mathrm{L}$ \\
\hline Ca値 & $6.8 \mathrm{mg} / \mathrm{dl}$ & $6.8 \mathrm{mg} / \mathrm{dl}$ & $6.9 \mathrm{mg} / \mathrm{dl}$ & $6.7 \mathrm{mg} / \mathrm{dl}$ & $7.3 \mathrm{mg} / \mathrm{dl}$ \\
\hline $\mathrm{HCO}_{3}{ }^{-}$ & 26.6mEq/L & $33.5 \mathrm{mEq} / \mathrm{L}$ & $29.5 \mathrm{mEq} / \mathrm{L}$ & $28.1 \mathrm{mEq} / \mathrm{L}$ & $32.0 \mathrm{mEq} / \mathrm{L}$ \\
\hline Anion gap & 8.4 & 1.5 & -1.5 & 2.9 & 1.0 \\
\hline 血糖値 & $399 \mathrm{mg} / \mathrm{dl}$ & $235 \mathrm{mg} / \mathrm{dl}$ & $252 \mathrm{mg} / \mathrm{dl}$ & $156 \mathrm{mg} / \mathrm{dl}$ & $142 \mathrm{mg} / \mathrm{dl}$ \\
\hline BUN 值 & $94 \mathrm{mg} / \mathrm{dl}$ & $40 \mathrm{mg} / \mathrm{dl}$ & $28 \mathrm{mg} / \mathrm{dl}$ & $18 \mathrm{mg} / \mathrm{dl}$ & $12 \mathrm{mg} / \mathrm{dl}$ \\
\hline 浸透圧 & $331 \mathrm{mOsm} / \mathrm{kg}$ & $326 \mathrm{mOsm} / \mathrm{kg}$ & $302 \mathrm{mOsm} / \mathrm{kg}$ & $292 \mathrm{mOsm} / \mathrm{kg}$ & $285 \mathrm{mOsm} / \mathrm{kg}$ \\
\hline $\mathrm{pH}$ & 7.410 & 7.490 & 7.510 & 7.500 & 7.490 \\
\hline $\begin{array}{l}\text { Base } \\
\text { excess 值 }\end{array}$ & $1.8 \mathrm{mEq} / \mathrm{L}$ & 9.3mEq/L & $6.0 \mathrm{mEq} / \mathrm{L}$ & $4.5 \mathrm{mEq} / \mathrm{L}$ & $7.9 \mathrm{mEq} / \mathrm{L}$ \\
\hline CRP值 & $22.72 \mathrm{mg} / \mathrm{dl}$ & $13.31 \mathrm{mg} / \mathrm{dl}$ & $9.51 \mathrm{mg} / \mathrm{dl}$ & $9.76 \mathrm{mg} / \mathrm{dl}$ & $7.48 \mathrm{mg} / \mathrm{dl}$ \\
\hline
\end{tabular}

補正 $\mathrm{Na}$ 值 $=($ 血糖值 -100$) / 100 \times 1.6+$ 実測 $\mathrm{Na}$ 值

\section{IV 考 察}

DKA は，インスリンの作用不足による糖利用低 下と脂肪分解異常㐫進を病態とした高度の代謝失調 状態である ${ }^{1)}$. DKAの約 20〜25\%は，感染症が発 症誘因であると報告されており ${ }^{1)}$ ，本症例でも下腿 壊疽による敗血症が誘因と考えられた。本症例は， 救急搬送時の $\mathrm{pH}$ 值, $\mathrm{HCO}_{3}^{-}$值, アニオンギャップ值, 意識状態の所見から重症のDKA と診断された ${ }^{2)}$. 本症例の周術期管理においてさまざまな問題点を経 験したので，以下に考察する。

\section{(1)麻酔管理}

DKA では, $100 \mathrm{ml} / \mathrm{kg}$ の水分喪失を伴うショック 状態であるため ${ }^{2)} に$, 脊髄くも膜下麻酔は禁忌と考 えられた。本症例では，自発呼吸下の静脈麻酔薬に よる管理を行った。罹病期間の長い糖尿病患者の約 3〜4割で，環軸後頭骨関節での配糖体沈着による 可動域制限があるために，気道確保が困難である ${ }^{3)}$ ことから自発呼吸下で管理した。しかし，意識障害 の合併や糖尿病患者における胃排出能の低下 ${ }^{4}$ か ら，嘔吐による誤與性肺炎の危険性が考えられた。 さらに, 術後の痙攣重積発作により気管扦管が必要
とされたことからも，術中から気管挿管やラリンジ アルマスクによる呼吸管理を考慮すべきであったと 反省させられた。

(2)アシドーシスの補正

術中にカテコラミン抵抗性の低血圧を認めたが, 重炭酸ナトリウムの投与で血圧は上昇した。重度ア シドーシスでは，心機能が抑制されカテコラミンの 効果が減弱すると報告されている ${ }^{5)}$ 。また, $\mathrm{pH}$ が6.9 未満で循環動態が不安定な場合には，重炭酸ナト リウムの投与が推奨されている ${ }^{6}$ ことから本症例で も施行した。しかし急激に補正すると，低カリウム 血症や脳浮腫による神経学的障害をかえって悪化さ せる可能性があるため ${ }^{7)}$ ，その投与の際は，急激な 補正とならないように慎重に行うべきと考えられた。 (3)痛覚の評価

糖尿病性神経障害は罹病期間が長く，網膜障害・ 腎障害・血行障害を合併した糖尿病症例で発症しや すいと報告されている ${ }^{8)}$. 本症例でも，これらの所 見が認められ，実際に創部洗浄時の痛覚反応が乏し かったこと，ショック時でも心拍数が増加しなかっ たことから，糖尿病性神経障害が予測された。術中 のケタミン投与量は水野らの報告 ${ }^{9}$ を参考とした。 
本症例の疼痛管理に問題はなかったが，その評価は 難しく，鎮痛薬の投与量の決定には議論の余地があ ると考えられた。

(4) 意識障害と術後の痤攣重積発作

DKAでは，血漿浸透圧の上昇によって脳神経細 胞内脱水が起こり, 意識障害や痤攣発作を発症しや すい ${ }^{10)}$. 周術期の輸液療法や血糖降下療法により, 血糖值やBUN 值は低下したが, 血清 $\mathrm{Na}$ 值が逆に 上昇したために，血漿浸透圧值はあまり低下せず， 術後に痤攣重積発作を発症するなど神経学的障害の 回復は緩徐であった。DKAでは高血漿浸透圧によ って, 細胞内から細胞外へ水の移動 ${ }^{2)}$ が生じて, 救 急搬送時のように見かけの血清 $\mathrm{Na}$ 值 $(132 \mathrm{mEq} / \mathrm{L})$ は低值を示すことがある。しかし，血糖值が $100 \mathrm{mg} / \mathrm{d} l$ 上昇するごとに見かけの血清 $\mathrm{Na}$ 值は

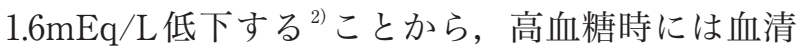
$\mathrm{Na}$ 值を補正することが重要である。救急搬送時の 補正血清 $\mathrm{Na}$ 值は $149 \mathrm{mEq} / \mathrm{L} て ゙$, 術後早期の補正血.

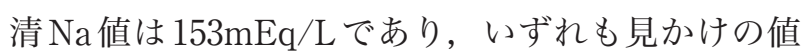
よりも高值であった。輸液療法として救急搬送時よ り $0.9 \%$ 生理食塩水を選択したために, 高 $\mathrm{Na}$ 血症を 助長し神経症状の回復を遅らせる結果となってしま ったが，DKAでは見かけの血清 $\mathrm{Na}$ 值ではなく補正 血清 $\mathrm{Na}$ 值を算出し, 輸液療法によって高 $\mathrm{Na}$ 血症 を助長しないように $0.45 \%$ 生理食塩水などの選択 ${ }^{2)}$ も考慮すべきであると考えられた。

(5)術後の洞不全症候群と心静止

洞不全症候群と炎症との関連性が報告されてお $り^{11)}$, 本症例でも, 下腿壊疽からの敗血症による炎 症が洞不全症候群を誘発した原因の一つと考えられ た。また, 血清カリウム值は, 血糖降下療法や輸液 療法によって順調に低下し正常範囲内となったが, 一方で低カルシウム血症を認めた。このために心収 縮力の低下や徐脈性不整脈 ${ }^{12)}$ をき起こしやすくな り, 結果として洞不全症候群を助長した可能性があ ると考えられ, 周術期の積極的なカルシウムの補正 を行うべきであったと反省させられた。

\section{結 語}

敗血症を起因とした重症DKA における緊急大腿 切断術の周術期管理を経験した。脱水, 電解質, 血 糖值，アシドーシスなどを補正しながら，続発する 多くの合併症に対する集学的治療が周術期管理にお いて重要であると考えられた。

\section{参考文献}

1) Chiasson JL, Aris-Jilwan N, Bélanger R, et al. : Diagnosis and treatment of diabetic ketoacidosis and the hyperglycemic hyperosmolar state. CMAJ 168:859866, 2003

2）目黒周, 渥美義仁：糖尿病性ケトアシドーシス, 非ケ トン性昏睡. Modern Physician 24：176-181，2004

3) Hogan K, Rusy D, Springman SR : Difficult laryngoscopy and diabetes mellitus. Anesth Analg 67 : 11621165,1988

4）青山雅, 姫井孟: 糖尿病神経障害. 糖尿病ケア 4:362366, 2007

5) Tajimi K, Kosugi I, Hamamoto F, et al. : Plasma catecholamine levels and hemodynamic responses of severely acidotic dogs to dopamine infusion. Crit Care Med 11 : 817-819, 1983

6) Kitabchi AE, Umpierrez GE, Murphy MB, et al. : Hyperglycemic crises in adult patients with diabetes : a consensus statement from the American Diabetes Association. Diabetes Care $29:$ 2739-2748, 2006

7) Marcin JP, Glaser N, Barnett P, et al. : Factors associated with adverse outcomes in children with diabetic ketoacidosis-related cerebral edema. J Pediatr 141 : 793-797, 2002

8）山本浩靖, 大月道夫, 高木美紀ほか：糖尿病患者にみ られる神経障害の自覚症状の特徵。新薬と臨彇 52 : 138-144, 2003

9）水野樹，杉本清治，大森貴夫ほか：ケタミン持続点滴 療法が奏効した断端痛の 1 症例. 麻酔 $50: 770-772$, 2001

10）石田俊彦：糖尿病患者の昏睡の診断と治療. 診断と治 療 $91: 1701-1705,2003$

11）保屋野真：心房細動誘発に扔ける炎症の役割について の実験的検討。新潟医学会雑誌 $123: 442-454,2009$

12）白石順, 駒場大峰, 深川雅史 : 高・低カルシウム血症. 治療 $91: 1064-1068,2009$ 


\title{
Perioperative Management of Above-the-knee Amputation in a Patient with Severe Diabetic Ketoacidosis
}

\author{
Atsushi KOTERA, Seiji KOUZUMA, Naoki MIYAZAKI, \\ Kenichiro TAKI, Kimiaki ESAKI
}

Department of Anesthesiology, National Hospital Organization Kumamoto Medical Center

The patient was a 57-year-old male. He was unconscious and a necrotic lesion was detected in his right leg. Because of the laboratory findings and clinical features, he was diagnosed as having severe diabetic ketoacidosis.

Above-the-knee amputation was scheduled to control bacteremia. Anesthesia was maintained with ketamine, fentanyl, and propofol under his own airway without tracheal intubation. During perioperative management, we encountered the following five problems ; 1) the method of anesthetic management, 2) adequate correction of severe metabolic acidosis, 3) estimation of pain in the patient with diabetic neuropathy, 4) unconsciousness and systemic convulsion, and 5) cardiac arrest and refractory arrhythmia. However, because of the intensive care, he recovered.

Key Words : Diabetic ketoacidosis, Perioperative management, Diabetic neuropathy

The Journal of Japan Society for Clinical Anesthesia Vol.31 No.4, 2011 